play for in creating credible, effective, and mutually supportive global and regional trading and development policies.

\author{
Peter Clegg (C) 2014 \\ University of the West of England, Bristol \\ http://dx.doi.org/10.1080/00358533.2014.986939
}

\title{
PSI Kingmaker: Life, Thought and Adventures of Peter Serracino Inglott
}

Daniel Massa

Valletta, Allied Newspapers Ltd, 2013, pp. 842, ISBN $97899909-31792$ (paperback)

For those interested in what anthropologist Jeremy Boissevain calls 'big man' politics, we have a rich literature that has explored and documented the rise and rise (and occasional fall) of various political figures, especially those that tower in small state constituencies. It is here that government is lean and transparent, where decision-makers are known and personally accountable, where decision-makers can amass considerable clout by assuming positions of power and influence in multiple institutions, and where rich networking suggests that everything is possible to those who are well placed. From Singham's review of Premier Eric Gairy of Grenada in the aptly titled Hero and Crowd in a Colonial Polity (1968) to David Hanlon's just published political biography of the Federated States of Micronesia's Tosiwo Nakayama (2014), we have been offered glimpses into the emergence of powerful charismatic politicians, their dramatic ascent to power, wily grip of popular sentiment, and extensive impact on public policy, not necessarily in that order. Much rarer are insights of those who support politicians in their task: crafting imaginative policies, articulating ideas, mediating tensions, and repackaging dull policies into winnable electoral fodder. These would be at the sidelines of political contests but not quite beyond the public gaze. These are the kingmakersyes, often men - who may rise to amass considerable political and social capital. Kingmakers may be even more powerful than the elected politicians that they notionally serve, as they do not have to be elected.

Such is the background to this overwhelming study of Peter Serracino Inglott (PSI, 1936-2012), priest, rector of the University of Malta, special advisor to the prime minister of Malta, chair of the Commonwealth Science Council, president of the Association of Commonwealth Universities ... 'arguably the most intelligent person in the Mediterranean'. He penned the electoral manifesto of the Nationalist Party for the 1987 election, and for many he was considered for some time to be the equivalent of a super-minister, even though without political portfolio. His democratic socialism knew no bounds: in my last encounter with him, he urged me to consider how we could set up a workers' cooperative to bid for work at the recently privatised Malta Shipyards.

For those of us, like myself, who knew the man, he was the 'Lord of the Rings'spin doctor, philosopher, mentor, aesthete, polyglot, wannabe clown. When I was an undergraduate student at the University of Malta, I sat in one of PSI's lectures on Marxism, and emerged with a palpable sense of failure: I had lost the thread of the argument. Perhaps his enthusiasm to get powerful ideas - such as that of the dialogic society- to transmute into actual policy got him too close to the political elite. Perhaps his sharp 
and eclectic mind was too driven to fathom alternative points of view and tolerate dissent. He was, to some, 'the infamous red-haired priest'.

For the many others who were cheated of, or spared, the privilege of knowing him, PSI's story, told in considerable, perhaps at times excessive, detail in this book, is not just the journey of a man (also searching for his God, by the way), but an oblique study of the economic and political development of Malta during most of its turbulent 20th century history. PSI was a witness, sometimes an actor, of important national and international events-including Malta's pre-eminent contribution to the United Nations of the notion of the sea as common heritage of (hu)mankind. PSI was behind that too. From Malta's saga during World War II, the winding road to political independence, the looming threat of political violence and thuggery, the promises and disappointments of a Christian democratic government post-1987, to the reconstitution of the University of Malta-readers will appreciate these windows into the development of this European island microstate.

There are many, many snippets that will delight the reader in this very frank book. Such as when PSI was meant to fly out of Malta, but his passport had expired (friends of friends in high places produced a new one within a few hours, which he then immediately set about trying to lose).

Although the author is very close to his subject in more ways than one (Professor Massa was also born in 1936 and knew 'Father Peter' very well), this text is no hagiography. We get to see many aspects of the kingmaker, 'warts and all'. And that is how it should be. In the University Council chamber, adorned by portraits of past university rectors, that of PSI is of an unkempt but smiling figure, accompanied by a clown.

\section{References}

Hanlon, D. (2014) Making Micronesia: A Political Biography of Tosiwo Nakayama. Honolulu HI: University of Hawaii Press.

Singham, A. W. (1968) The Hero and the Crowd in a Colonial Polity. New Haven, CT: Yale University Press.

\section{Confronting the Colonies-British Intelligence and Counterinsurgency}

Rory Cormac

London, Hurst, 2013, pp. 295, ISBN 9781849042932 (hardback)

'MI6 had been disadvantaged because it was not porous enough. It was a bit defensive towards outsiders.' This remark by Sir John Sawers, the 'UK's spy chief', made during lunch at a Pimlico restaurant and reported recently by the editor of a salmon-pink weekend newspaper, hints at the kind of issues and attitudes that animate Confronting the Colonies. The book provides a sober and, indeed, for any reflective person in an age of rapid change, a sobering intimate glimpse of how intelligence gathering influences 